YEARBOOK of ANTITRUST and REGULATORY

STUDIES www.yars.wz.uw.edu.pl
Peer-reviewed scientific periodical, focusing on legal and economic issues of antitrust and regulation. Creative Commons Attribution-No Derivative Works 3.0 Poland License.

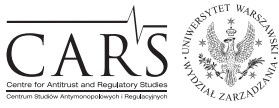

Centre for Antitrust and Regulatory Studies, University of Warsaw, Faculty of Management www.cars.wZ.uw.edu.pl

\title{
Resale Price Maintenance in Poland - Further Steps to Its Liberalization or Stuck in a Status Quo?
}

\author{
by
}

Dariusz Aziewicz*

\section{CONTENTS $^{* *}$}

I. Introduction

II. Standards of assessment of minimum or fixed Resale Price Maintenance - a long way to economic understanding

III. A more liberal approach to minimum or fixed Resale Price Maintenance taken by the European Commission?

IV. Minimum or fixed Resale Price Maintenance in Poland - current approach

V. Is if still justified to qualify minimum or fixed Resale Price Maintenance in Poland as an agreement restricting competition 'by object'?

VI. Conclusions

\section{Abstract}

Due to the recognition of their positive market effects, the evolving approach to minimum or fixed resale price maintenance (RPM) creates, in many countries, the requirement of analyzing their true economic outcomes. In the light of newest judgments delivered by the Polish Supreme Court, the purpose of this article is to analyze if it is still justified to qualify RPM as a multilateral practice that restricts competition 'by object' under Polish law.

\section{Resumé}

Lapproche évolutive à l'égard de l'imposition de prix de revente fixes, ou de prix de revente minimaux, en raison de la reconnaissance de leurs effets positifs sur

* LL.M. in Comparative law (University of Florida), PhD candidate, Department of European Economic law, Faculty of Management, University of Warsaw; darek.aziewicz@gmail.com.

** Article received: 15 November 2016; accepted: 5 June 2016. 
le marché, constitue dans de nombreux pays une obligation d'analyser les vrais résultats économiques de cette pratique.

Cet article vise à analyser si, à la lumière des plus récents jugements de la Cour suprême en Pologne, il est toujours juste de qualifier le maintien des prix de revente en vertu de la loi polonaise de la concurrence comme un accord, qui a pour son objet de restreindre le jeu de la concurrence.

Key words: consumer welfare; economic approach; Resale Price Maintenance; restrictions by effect; restrictions by object; vertical agreements

JEL: K21

\section{Introduction}

Minimum or fixed resale price maintenance (hereafter, RPM) is among the most commonly used market practices that may potentially bring harm to competition. As such, such market behaviors are one of the most interesting aspects of competition law when it comes to the implementation of appropriate evaluation standards ${ }^{1}$. In 2007, the U.S. Supreme Court delivered the seminal Leegin Creative Leather Products Inc. v. PSKS, Inc. judgment ${ }^{2}$. Therein, it applied the rule of reason evaluation standard to RPM, despite the fact the per se standard has been applied to such cases in the past. The Leeging judgment retained RPM's status of one of the issues most widely analyzed by competition law scholars and competition protection authorities.

This article will first analyze the standards of assessment of RPM applied under US federal antitrust law and EU competition law, together with their economic grounds. Presented next will be the two latest judgments of the Polish Supreme Court, which concern the evaluation of RPM. Simultaneously, the paper will analyze how the shift in the approach to RPM taken by US and EU authorities influenced Polish competition law practice, in particular the judgments of the Polish Supreme Court. Finally, an attempt will be made to evaluate if it is still justified to qualify minimum or fixed RPM in Poland as an agreement that restricts competition 'by object'.

\footnotetext{
1 On the other hand maximum resale prices are mostly recognized as legal until no anticompetitive effects arise.

${ }^{2}$ Leegin Creative Leather Products, Inc. v. PSKS, Inc., 551 U.S. 877, 127 S. Ct. 2705, 168 L. Ed. 2d 623 (2007).
} 


\section{Standards of assessment for minimum or fixed RPM - a long way to economic understanding}

Minimum (or fixed) RPM is an agreement concluded between undertakings on different levels of the distribution chain (upstream and downstream) that, as a condition of being able to sell a product, creates a price floor (or fixed price level) for the retailer below which the latter cannot go. It has long since been recognized that the only goal of RPM is to impede competition by eventually raising prices above their competitive level. US federal antitrust law, EU competition law as well as Polish competition law regimes have all recognized RPM as a restriction which impedes competition prima facie. Thus, as one of the most dangerous multilateral practices from the perspective of competition protection, RPM was seen as a restriction that should always be banned.

Following the Dr. Miles judgment of 1911, US federal antitrust law has for over 90 years recognized that 'Contracts between a manufacturer and all dealers whom he permits to sell his products, comprising most of the dealers in similar articles throughout the country, which fix the price for all sales, whether at wholesale or retail, operate as a restraint of trade, unlawful both at common law and as to interstate commerce, under the antitrust act of July $21890^{\prime 3}$. This statement has been later recognized as constituting a per se standard of evaluation for RPM in US federal antitrust law ${ }^{4}$. Therefore, the illegality of RPM has been assumed regardless of its market effects and without the necessity of analyzing them ${ }^{5}$. However, not all practices constituting a de facto RPM have been illegal per se under US antitrust laws. This was the case as the Fair Trade Acts $^{6}$ and the Collgate doctrine ${ }^{7}$ have been established by US

\footnotetext{
${ }^{3}$ Dr. Miles Med. Co. v. John D. Park \& Sons Co., 220 U.S. 373, 378, 31 S. Ct. 376, 377, 55 L. Ed. 502 (1911).

${ }^{4}$ See: United States v. Colgate Co., 250 U.S. 300 (1919); FTC v. BeechNut Packing Co., 257 U.S. 441 (1922).

5 See: Northern Pac. Ry. Co. v. United States, 356 U.S. 1, 5 (1958): 'However, there are certain agreements or practices which, because of their pernicious effect on competition and lack of any redeeming virtue, are conclusively presumed to be unreasonable, and therefore illegal, without elaborate inquiry as to the precise harm they have caused or the business excuse for their use. This principle of per se unreasonableness not only makes the type of restraints which are proscribed by the Sherman Act more certain to the benefit of everyone concerned, but it also avoids the necessity for an incredibly complicated and prolonged economic investigation into the entire history of the industry involved, as well as related industries, in an effort to determine at large whether a particular restraint has been unreasonable -- an inquiry so often wholly fruitless when undertaken'.

6 See: Miller-Tydings Fair Trade Act 50 Stat. 693, and Mcguire Act, 66 Stat. 631.

7 See: United States v. Colgate Co., 250 U.S. 300 (1919).
} 
Congress and the US Supreme Court in the XX Century ${ }^{8}$. Moreover, the per se standard of evaluation for RPM has been criticized by most competition law scholars. Criticism started in the works of (Telser, 1960) while (Hovenkamp, 2005) described the Dr. Miles judgment as 'The most unfortunate development in the law of RPM'. In 2007, the US Supreme Court finally overruled the Dr. Miles stare decisis (Elhauge, 2007). In the aforementioned Leegin judgment, the US Supreme Court stated in accordance to RPM that 'the accepted standard for testing whether a practice restraints trade in violation of (sec) 1 is the rule of reason'9. It is important to note that after the shift to the rule of reason standard the burden of proof (of anticompetitive effects) is imposed on the plaintiff, not the undertaking suspected of breaching competition law provisions.

The US Supreme Court criticized in the Leegin case the old common law rule ('general restraint upon alienation is ordinarily invalid') used as a basis for the Dr. Miles judgment and stated that it may not constitute grounds for evaluation of minimum RPM in an economic environment of the XXI Century ${ }^{10}$. It declared that the reason for this shift was that the formalistic per se approach fails to demonstrate any economic effects of RPM ${ }^{11}$. The US Supreme Court emphasized also that it has unjustly treated vertical restraints analogously to those of a horizontal nature pointing out that Dr. Miles failed to consider the differences in their economic consequences ${ }^{12}$.

The US Supreme Court justified the shift to the rule of reason ${ }^{13}$ by stating that economic literature is full of pro-competitive justifications for minimum $\mathrm{RPM}^{14}$. In its judgment, it recognizes three basic pro-competitive effects of RPM.

The first is the stimulation of inter-brand competition, which means competition among manufacturers selling different brands in the same product

8 See also: United States v. General Electric Co.272 U.S. 476 (1926) on usage of RPM in the consignment agreements; as well as Simpson v. Union Oil Co. 377 U.S. 13 (1964); Morrison v. Murray Biscuit Co., 797 F.2d 1430, 1436 (7th Cir. 1986).

${ }^{9}$ Leegin, Creative Leather Products, Inc., 551 U.S. 877.

10 Ibidem at 888 .

11 Ibidem,

12 Ibidem.

13 Board of Trade of City of Chicago v. United States, 246 U.S. 231, 238, 38 S. Ct. 242, 244, 62 L. Ed. 683 (1918): 'the true test of legality under $\S 1$ of the Sherman Act, which prohibits a contract, combination, or conspiracy in restraint of trade, is whether the restraint imposed is such as merely regulates and perhaps thereby promotes competition or whether it is such as may suppress or even destroy competition, and to determine that question the court must ordinarily consider: the facts peculiar to the business to which the restraint is applied; its condition before and after the restraint is imposed; and the nature of the restraint and its effect, actual or probable'.

14 Leegin, Creative Leather Products, Inc., 551 U.S. 888. 
market ${ }^{15}$. The US Supreme Court applied here the reasoning from the earlier Kahn case where (while using the rule of reason standard for maximum RPM) it had stated that 'the primary purpose of the antitrust laws is to protect [this type of] competition'16. Minimum RPM stimulates inter-brand competition by reducing intra-brand competition, competition among retailers selling the same brand of products. This approach is based upon an assumption that if all dealers have the same prices, then all of them will look for different areas of competition to win the market game. As a result, after the imposition of minimum RPM, retailers will mostly compete on the services level. This will lead to an increase of the number of services in stores to the optimal level. Hence, the number of sales should increase (Telser, 1960). It is so because the demand for a differentiated product is not only stimulated by the price but also by other factors such as: quality, design, or customer service ${ }^{17}$. Better customer service increases consumers demand (Elzinga and Mills, 2010). Finally, even though empirical studies show that price in markets containing minimum RPM is usually higher than on markets without it, the price level is not the only factor determining consumer welfare ${ }^{18}$. Hence, the US Supreme Court stated that even though minimum RPM may lead to higher prices, it does not necessarily tell us everything about welfare effects since its final result is generally based upon the existence of both pro- and anti-competitive effects ${ }^{19}$. This, so called 'service hypothesis' indicates that the 'increase in demand resulting from enhanced service, elicited trough a protected retail margin, will more than offset a negative impact on demand of a higher retail price' (Mathewson and Winter, 1998).

The second pro-competitive effect mentioned in the Leegin judgment is the fact that minimum RPM is a reasonable defense against free-riders (Bork, 1978). Free-riders are maverick market players who capture demand generated by services of other players. Lack of services in their (free-riders) stores, allows them to offer discounts. For instance, the customer will go to a well-equipped retailer whose knowledgeable staff explains the product. Afterwards, the customer leaves and buys the product in a free-rider's store below the initial distributor's price, since the customer no longer needs an explanation. Eventually, the result of a free-riders problem is a drop in the sales as well as service effort by all retailers, and in fact, a reduction in consumer welfare, as the amount of services decreases since they are unprofitable (Bork, 1978). A free-rider can also affect the image of the manufacturer's product

\footnotetext{
15 Ibidem 890.

16 Cont'l T. V., Inc., 433 U.S. at 51-52.

17 Ibidem.

18 Ibidem.

19 Leegin, Creative Leather Products, Inc., 551 U.S. at 895.
} 
and, ultimately, its effectiveness (Hovenkamp, 2005). Some manufacturers want to maintain a high level of services to protect the margins of retailers with a good reputation.

The third pro-competitive effect mentioned in the Leegin judgment is the facilitation of new market entry since entrepreneurs can use RPM as part of an aggressive distribution program that induces retailers to make capital and labor investments ${ }^{20}$. RPM will assure new entrants that prices will not go below a specified level so that they will be able to recover their expenses made on advertising and entry costs ${ }^{21}$.

On the other hand, the US Supreme Court also indicated situations which cause anti-competitive effects of minimum RPM. First, minimum RPM may be qualified as cartel facilitators on both retail and manufacturers' levels (it may prevent cheating within a cartel). It may work as a tool for a hub-andspoke cartel where retailers are fixing prices and are simultaneously supervised (monitored) by a manufacturer who is setting a minimum RPM. It may also facilitate collusion by manufacturers due to retail price transparency. The US Supreme Court also indicated that a dominant manufacturer may foreclose other manufacturers from the market (market foreclosure) ensuring that some retailers retain attractive profit margins in exchange for refusing to deal with other manufacturers ${ }^{22}$.

\section{A more liberal approach to minimum or fixed RPM taken by the European Commission?}

The described turn in the Leegin case started a world-wide discussion over the most appropriate evaluation standard for RPM. Today, pro-competitive effects of RPM identified by antitrust scholars are explicitly recognized by other than US antitrust authorities. For instance, a liberalized approach has been incorporated into the soft law of the European Commission. Importantly however, while US antitrust law applies the economic evaluation standard based on the total welfare approach, EU law is mostly basing its approach on the consumer welfare standard. In practice therefore, their approaches to the same market practices may vary. Still, approaches based on the evaluation of market effects are possible under both regimes.

European competition law recognizes two standards applied to multilateral market practices - (i) restrictions 'by object' and (ii) restriction 'by effect'

\footnotetext{
20 Leegin, Creative Leather Products, Inc...., 551 U.S. 890.

21 Ibidem at 891.

22 Ibidem.
} 
(Jones, 2014).The European Commission indicated a liberalized approach to RPM just three years after the Leegin judgment in its Guidelines on Vertical Restraints of $2010^{23}$. The latter lists, on the one hand, the anti-competitive effects of RPM. On the other hand, they directly give examples of cases when RPM may lead to efficiencies and may thus be assessed under Article 101(3) TFEU (in fact, a structured rule of reason) ${ }^{24}$. These examples include: (i) when a manufacturer introduces a new product, RPM may be helpful during the introductory period of expanding demand to induce distributors to better take into account the manufacturer's interest to promote the new product; (ii) when it is necessary to organize in a franchise system or similar distribution system applying a uniform distribution format, a coordinated short term low price campaign ( 2 to 6 weeks in most cases); (iii) in some situations, the extra margin provided by RPM may allow retailers to provide (additional) presales services, in particular in case of experience or complex products (elimination of the free rider problem) $)^{25}$.

The above examples clearly shows that the European Commission took into account the reasoning provided by economic literature while drafting its new Vertical Guidelines. However, in EU competition law, RPM seems to be still qualified as a restriction 'by object', which based on the above examples may be rehabilitated only under Article 101(3) TFEU. This maintains a standard of presumptive illegality for minimum RPM and, most importantly, shifts the burden of proof (of its pro-competitiveness) onto undertakings ${ }^{26}$. Moreover, the standard of proof in accordance with the necessity of jointly meeting all of the prerequisites established in Article 101(3) TFEU is very high ${ }^{27}$.

\section{Minimum or fixed RPM in Poland - current approach}

Like most competition law regimes, Polish legislation distinguishes two types of standards for evaluating multilateral market practices - those prohibited only for the fact of their very existence, and those, which the effects of which must be tested. Polish law follows in this context the rules of EU competition

23 Commission notice - Guidelines on Vertical Restraints (OJ 2010 C 130/01).

24 Article 101(3) of the Consolidated version of the Treaty on the Functioning of the European Union, Official Journal of the European Union (OJ 2016 C 202).

25 Guidelines on Vertical Restraints, para. 225.

26 26/76 Metro-SB-Grossmarkte GmbH v. Commission, ECLI:EU:C:1977:167, para 21: 'price competition is so important the it can never be eliminated'.

27 See for e.g: Commission Decision 82/123/EEC of 25 November 1981 relating to a proceeding under Article 85 of the EEC Treaty (IV/428 - VBBB/VBVB) (OJ L 54/36). 
law. It divides anti-competitive multilateral practices into (i) those restricting competition 'by object', and (ii) those restricting competition 'by effects'. The first type covers mostly the so-called hardcore restrictions which, to be prohibited, do not require evidence of any anti-competitive influence on the relevant market. The second type of restrictions are those with reference to which the antitrust authority - before indicating their anti-competitiveness in an administrative decision - has to prove an anti-competitive influence (effect) on competition.

Like in EU competition law, according to Polish legislation an undertaking may always try to prove that a multilateral practice ultimately brings positive effects for competition. Also in this case, the burden of proof shifts to the defendant who has to meet all of the prerequisites established in Article 8(1) of the Act on Competition and Consumers Protection (hereafter, uokik) (in fact, a structured rule of reason $)^{28}$. In practice, such an 'individual' exemption is hardly ever proven for practices restricting competition 'by object'29.

In the decisional practice of the Polish Competition Authority (hereafter, UOKiK), RPM has been recognized as an agreement restricting competition 'by object' ${ }^{30}$. On the other hand, scholars mostly argue that RPM should be treated as an agreement restricting competition 'by effect' (Jurkowska Gomułka, 2012; Grzejdziak, 2009; Aziewicz, 2013), albeit other opinions are also expressed (Turno, Zawłocka -Turno, 2011; Bolecki, 2013).

At this point, it is worth analyzing two judgments of the Polish Supreme Court concerning RPM. First, in the opinion delivered by the Supreme Court in the judgment of 23 November 2011 (Ref. No. III SK 21/11) (11 $^{31}$ is possible to find statements that express at least the recognition of a more liberal approach to RPM.

To clarify the context of the judgment, in a decision issued on 29 June 2007 the President of UOKiK held that an agreement concluded between Roben Ceramika Budlowlana (a tile manufacturer) and twenty of its distributors constituted an anti-competitive vertical agreement setting fixed resale prices ${ }^{32}$.

28 Article 8 (1) and (2) of the Act of 16 February 2007 on Competition and Consumer Protection (Consolidated text: Journal of Laws 2015, items 184, 1618, 1634).

${ }^{29}$ For RPM see decisions of the UOKiK President: of 16 July 2010, No. DOK-6/2010; of 4 November 2011, No. RKT-33/2011.

30 See decisions of the UOKiK President: of 27 December 2012, No. DOK-8/2012; of 30 December 2008, No. RPZ-50/2008 and judgment of the Court of Appeals in Warsaw of 5 September 2012, Ref. No. VI ACA 363/12. Also the Polish Block Exemption excludes RPM from its scope see: para. 11 of the Regulation of the Council Of Ministers of 30 March 2011 on the exemption of certain types of vertical agreements from the prohibition on competition restricting agreements (Journal of Laws 2011 No. 81, item 441).

31 Judgment of the Polish Supreme Court of 23 November 2011, Ref. No. III SK 21/11.

32 Decision of the UOKiK President of 29 June 2009, No. RWR-20/2007. 
The agreement concerned letters sent by the manufacturer to its distributors informing them that starting from 12 July 2005 Roben was going to introduce a promotion on one of its tile types. The promotion was construed in such a way that the distributors had to sell this specific type of tiles for a fixed price per square meter. Later on, the distributors confirmed the implementation of the promotion by way of letters sent-back to the manufacturer.

First of all, the Polish Supreme Court stated that as a rule, vertical agreements between entrepreneurs in a free market economy are a key tool for the distribution network and are generally pro-competitive ${ }^{33}$. This is mainly because of their positive influence on competition between manufacturers of substitutable products, at the expense of decreasing intra-brand competition. Thus, interestingly, the Supreme Court attempted to state that the importance of inter-brand competition exceeds the importance of intra-brand competition. Hence, it presented an approach which is close to the pro-competitive justifications of RPM used for example in US antitrust law. Moreover, the Polish Supreme Court emphasized that having its own distribution chain might be too expensive for each particular manufacturer and so acting through distributors is a useful alternative to vertical integration. From an economic perspective, a distributor is in fact recognized as an entity acting on behalf of a manufacturer representing the latter before the clients; as such, the manufacturer wants to keep a certain level of control over distributors ${ }^{34}$. The Polish Supreme Court recognized therefore the basic economic aspects of distribution chains based upon transaction costs economics (Coase, 1937).

Despite such argumentation, the Supreme Court did not go any further in its assessment, in other words, it did not directly weight the pro- and anticompetitive effects of the agreement. The opposite is true in fact. The Court emphasized that vertical agreements, which have as their subject the setting of resale prices, are generally recognized as agreements having the restriction of competition as their object. According to the judgment, this is the "traditional approach' based upon the assumption that this type of agreement limits the freedom of the distributors to create their own pricing policy. Hence, the price policy is recognized in this judgment as important (or even crucial) from the perspective of competition protection.

Finally, the Polish Supreme Court stated also that alternatively to the Leegin judgment, RPM even nowadays should be recognized as an obvious competition restriction, irrespectively of their market effects. To support this position, the Court articulated specific anti-competitive effects of RPM. Despite the fact that in the first part of its opinion it indirectly recognized that inter-brand competition may be more important than intra-brand competition,

33 Judgment of the Polish Supreme Court of 23 November 2011, Ref. No. III SK 21/11.

34 Ibidem. 
it eventually stated the opposite. It also noted that a fixed resale price provokes a higher price than a price created by a fully competitive environment. Furthermore, the Polish Supreme Court emphasized that RPM prohibits competition between distributors of the same brand as well as between other brands. It stressed that vertically fixed prices may work as a cartel facilitator. It noted that fixed prices may negatively affect the level of production efficiency (if there is no price competition between sellers, the manufacturer will fell less of a price pressure to decrease the wholesale price). According to the Supreme Court, the same is true for distributors who will not be willing to decrease their operational costs if they do not feel a price pressure from other distributors. ${ }^{35}$ Again, all of the aforementioned anti-competitive effects focus on price competition as the key of competition protection. Conclusively, the Polish Supreme Court held that fixed resale prices raise concerns no matter what the values protected by competition law are. These findings lead the Court to the final conclusion that fixed resale prices restrict competition 'by object'.

Despite the fact that the 'traditional approach' to RPM was ultimately applied, this was the first time for the Polish Supreme Court to take a broad and detailed note of pro-competitive effects of fixed resale prices. These mentioned effects reflect, in fact, the pro-competitive justifications articulated by the European Commission in its Guidelines on Vertical Restrains of 2010. These are, first, easier market entry for certain producers - entrance of a new market player will always be pro-competitive because other market players will react by cutting their prices, or in any other way desired by consumers. Second, the Supreme Court recognized the economic concept of the free-riding effects, that is, the protection of a distributor who is providing a broad-scope of services against sellers not doing so (but charging lower prices). Yet the Polish Supreme Court stated that the free-rider effect is not working on all types of markets and that it does not have to effectively lead to better services of distributors since it is not requiring them directly to do so. Conclusively, in the Court's opinion, avoiding the free-rider effect may justify the use of RPM only in exceptional circumstances. Third, it was noted in the judgment that RPM might have pro-competitive effects as they may lead to a uniform image and character of the sales network as well as effective advertising campaigns charging lower prices.

Finally, the Polish Supreme Court declared that it has to respect the established standards of importance associated with price competition, which plays a foreground role for competition law enforcement. It stated that the independence in creating a pricing policy by market participants is one of the

35 Ibidem. 
most important issues for competition protection. Therefore, given the fact that the Polish Block Exemption Regulation states that pricing agreements are hardcore restrictions, the pro-competitive effects of such agreement may be analyzed only under the individual exemption rule.

The second judgment of the Polish Supreme Court worth noting here was delivered on 15 May 2014 (Ref. No. III SK 44/13 ${ }^{36}$ ). This judgment referred to the decision of the UOKiK President issued on 31 December 2008 concerning an anti-competitive price agreement on fixed resale prices between Zakłady Chemiczne Hajduki S.A. and its distributors on the Polish market of paints ${ }^{37}$. In the judgment, the Supreme Court consider mainly the issue of the amount of fine imposed by the UOKiK President, albeit the content of the judgment included also an important statement on the general treatment of RPM.

While delivering its opinion on the merits, the Polish Supreme Court stated that there are no grounds to accept the appeal. It implied that a multithreaded argumentation on the status of RPM has already been delivered in the aforementioned judgment III SK 21/11. It supported this argumentation by establishing a general classification of RPM as an agreement restricting competition 'by object'. However, the Polish Supreme Court also noted that such a qualification does not justify a uniformly rigorous approach to sanctions (financial fines) imposed by the UOKiK President for vertically fixed prices. While supporting this position, the Court stated that not every agreement stipulating fixed prices threatens the public interest or other values important for competition law as well as justifies the imposition of a fine (which is motivated each time be the realization of the public interest). The Polish Supreme Court held that there is a question of a public sense of a fine imposition on a concrete participant in an agreement in a situation when the direct income from the agreement constituted only a small amount of his total revenue.

\section{Is it still justified to qualify minimum or fixed Resale Price Maintenance in Poland as an agreement restricting competition by object?}

Arguments presented in the above judgments give room for an assessment whether it is still justified to qualify RPM as a practice restricting competition by 'object' under the Polish competition law regime.

\footnotetext{
36 Judgment of the Polish Supreme Court of 15 May 2014, Ref. No. III SK 44/13.

37 Decision of the UOKiK President of 31 December 2008, No. RKT 114/2008.
} 
First the realization should be recognized as correct that the Polish Supreme Court articulated in judgment III SK 44/13 that the amount of antitrust fine may not always be of the same height for each entrepreneur taking part in an anticompetitive practice. A fine should be calculated individually (case-by-case). However, the Court did not stop its argumentation here and went one-step further touching upon the potential restrain by RPM of the public interest, or other values important for competition law. This is a crucial statement since under Polish competition law 'values important for competition law' should be recognized as consumer welfare.

In order to analyze the aforementioned cases it is important to note the following arguments. First, the Competition and Consumer Protection Act determines the conditions for the development and protection of competition as well as the principles of protecting the interests of undertakings and consumers in the public interest ${ }^{38}$. Polish competition law scholars generally state that the protection of competition is not a goal in itself. The ultimate goal of competition law in Poland is the protection of consumer welfare. Such approach has been followed by the Polish Supreme Court which stated in the judgment of 19 October 2006 that: 'under this interpretation competition is a process of rivalry, which is protected in the scope in which it is connected with implication of stipulated, positive effects for consumers' ${ }^{39}$. Consumer welfare as the central goal of Polish competition policy is also articulated in the latest official documents of the Polish Competition Authority - the UOKiK President (UOKiK, 2014, p. 18) ${ }^{40}$. On the other hand, the President of UOKiK defines the notion of consumer welfare in his administrative decisions as 'final benefits which are coming from competition, as broader scope of choice, better quality, lower prices and higher innovation of products and services offered on the market' ${ }^{\prime 4}$. Thus, significantly, low prices are not recognized as the sole measure which at the end of the day makes consumers better off.

Second, in the light of the Competition and Consumer Protection Act, public interest constitutes a prerequisite for regulatory actions serving the protection of entrepreneurs and consumers (Skoczny, 2014). Public interest is a jurisdictional and interventional prerequisite. It makes the identification of the ultimate goal of competition protection, or its additional goals, possible ${ }^{42}$. Also in the light of the Polish Constitution, limitations upon the freedom of economic activity may be imposed only by means of a statute, and only for

38 Article 1 of the Act on Competition and Consumers Protection.

39 Judgment of the Polish Supreme Court of 19 October 2006, Ref. No. III SK 15/06 (OSNP 2007, No. 21-22, item 337).

40 UOKiK, Polityka konkurencji na lata 2014-2018, p. 18.

41 Decision of the President of UOKiK of 30 December 2011, No RPZ-39/2011.

42 Ibidem. 
important public reasons. Jurisprudence indicates moreover a 'correction role' of public interest, while it is serving as the prerequisite for intervention. This approach may apply when actions of entrepreneurs are formally breaching rules stipulated by the law, yet it may be deduced from the statements of facts that an intervention of the UOKiK is not necessary (in the light of ratio legis of the Competition and Consumer Protection Act) ${ }^{43}$.

Finally, Polish scholars indicate that the 'object' of an agreement is understood 'not only as subjective or objective motivation to actions of the parties to the agreement, but as an objective object of the agreement identical with its subject' (Stawicki, 2010). Polish courts, including the first instance court responsible for competition cases - the Court of Competition and Consumers Protection (hereafter, SOKiK) ${ }^{44}$, are off the opinion that when 'the object' is detected 'there is no need to prove the factual usage of an agreement by the entrepreneur ${ }^{35}$. Polish jurisprudence also implies that it is not important if the parties have been implementing the agreement of not ${ }^{46}$. Furthermore, statements can be found which emphasize that there is no necessity to analyze the impact of such agreement's effects ${ }^{47}$ and its anti-competitive character is present even if the parties have not achieved the expected financial benefits ${ }^{48}$. It should thus be recognized that anti-competitive agreements are qualified as 'restriction by object' only if they are of such kind that in most situations they harm consumer welfare, and this fact is so obvious that there is no need to prove it during administrative proceedings.

As (Faull and Nikpay, 2007) state (in accordance with agreements restricting competition 'by object' under EU law) - agreements of such kind 'prima facie' have as their object the restriction of competition. Thus, it is in fact the closest standard of evaluation to the US federal antitrust law per se standard. The per $s e$ standard in the US covers restrictions harming competition 'on its face', also called 'naked restrains', because they do nothing but harm competition without any offsetting benefits (Hovenkamp, 2005). Thus, it may be recognized that if it is 'the object' of an agreement to restrict competition, than it will always harm the values protected by competition law (consumer or total welfare). If (in case of Polish law) it always harms consumer welfare, it shall be excluded from the market by administrative actions taken by the relevant competition authority in the public interest. Yet the Polish Supreme Court directly states in

43 Judgment of the Polish Supreme Court of 3 October 2013, Ref. No. III SK 51/12.

${ }^{44}$ Court of Competition and Consumers Protection (SOKiK) is a civil court who acts in the first instance in appeals from administrative decisions issued by the President of UOKiK.

45 Judgment of SOKiK of 5 September 2005, Ref. No. VI ACa 76/06.

46 Judgment of SOKiK of 10 September 2003, Ref. No. XVII Ama 136/02.

47 Judgment of the Court of Appeals in Warsaw of 4 December 2007, Ref. No. VI ACa848/07.

48 Judgment of SOKiK of 7 November 2005, Ref. No. XVII Ama 26/04. 
the III SK 44/13 judgment that RPM is not always harming the public interest and other values important for competition law, and so it must be argued that it indirectly also states that RPM does not always harm consumer welfare.

Given the above, two approaches are possible. First, the court is open for an argumentation concerning the efficiencies of RPM based upon Article 8(1) of the Competition Act ${ }^{49}$ in situations described in the III SK 21/11 judgment. Simultaneously, this option envisages (as stated in the III SK 21/11 judgment) that RPM is still qualified as a competition restriction 'by object'. This approach opens however the door to the argumentation that an automatic shift of the burden of proof to the undertaking suspected of breaching competition law provisions may be contrary to Article 22 of the Polish Constitution. Article 22 of the Polish Constitution states that limitations upon the freedom of economic activity may be imposed only by means of statute and only for important public reasons (in case of the Competition and Consumer Protection Act - public interest) (Grzejdziak, 2009). However, such limitations should be also proportionate. Due to the fact that shifting the burden of proof in practice makes a justification of RPM rarely possible (especially in the light of the indispensability prerequisite), and on the other hand that their procompetitive effects are widely recognized, such shift should not necessarily be proportionate in the light of constitutional provisions.

Second, the alternative approach would be to recognize that the application of the 'by object' evaluation standard to RPM is not correct and that RPM should be recognized as a competition restriction 'by effect'. Three reasons support this statement, all of which contradict the argumentation grounds for the application of the 'by object' evaluation standard to RPM. First, the III SK 21/11 judgment mentions the key importance of intra-brand competition, yet competition is not the subject of protection by Polish antitrust law in itself - its ultimate goal is the protection of consumer welfare. The UOKiK President should thus each time separately evaluate which market circumstances are leading to the maximization of consumer welfare. In some cases, the stimulation of intra-brand competition may have a positive effect on consumer welfare. Other times, consumer welfare may benefit from the stimulation of inter-brand competition, even at the cost of intra-brand

49 Article 8 (1) of the Act states that: 'The prohibition referred to in Article 6, paragraph 1 shall not apply to agreements which at the same time:

1) contribute to improvement of the production, distribution of goods or to technical or economic progress;

2) allow the buyer or user a fair share of the resultant benefits;

3) do not impose upon the undertakings concerned such impediments which are not indispensable to the attainment of these objectives;

4) do not afford these undertakings the possibility to eliminate competition in the relevant market in respect of a substantial portion of the goods in question'. 
competition. It has to be argued that there is no reason to give the protection of inter- or intra-brand competition overall priority under Polish competition law. Second, RPM only reduces intra-brand price competition but it does not reduce, or enhances, other areas (dimensions) of competition between retailers. Economic literature shows that there may be different ways to achieve the optimal level of consumer welfare, depending on market circumstances and the practices under assessment. The Polish Competition Authority or courts should thus always remember what benefits the ultimate goal of its antitrust law in every particular case. Finally, as indicated above, the Polish judiciary states that the reason why RPM should always be banned is their negative effect on prices. However, as already mentioned, the Polish Supreme Court is clearly of the opinion that price competition (thus lowest prices for consumers) is not the only determinant of consumer welfare. It is so clearly because the demand curve (reflecting consumers' choices) may shift to the right not only because of low prices but also due to other aspects (Aziewicz, 2013). Therefore, giving priority to price competition is not only economically unreasonable, but also creates jurisprudential inaccuracy.

Finally, it is worth noting the contents of the new Competition Policy of the UOKiK President adopted by the Polish Council of Ministers in 2015 which indicates the policy trends for national competition law for forthcoming years. Therein a statement can be found whereby the assessment of vertical restrains should be conducted on an individual basis because such practices may generate benefits for consumers. Incidentally, the document makes that statement binding (a case-by-case analysis) on the Polish Competition Authority but not on market players. Moreover, the UOKiK President directly expressed the view that an intervention by the Authority against vertical relationships is only justified if an economic analysis shows that their anticompetitive effects are not countervailed by consumer benefits (UOKiK, 2015, p. 32). The UOKiK President has not said if this approach is (or is not) applicable to only specific market practices of a vertical character and so it should be assumed that RPM are also covered by its scope. The question however arises whether this approach will be sustained after recent change of the President of Polish competition authority.

\section{Conclusions}

Considering all of the above, it is not totally clear what type of evaluation standard is currently applicable to RPM under the Polish competition law regime. On the one hand, the Polish Supreme Court is clearly off the opinion 
that RPM are still considered to be a competition restriction 'by object'. On the other hand, an in-depth analysis of the text of its jurisprudence, in the light of an economic understanding of RPM, as well as the goals of Polish competition law, may lead to different conclusions. It is not clear in particular why the 'by object' designation should be applicable to market practice which may not always harm the public interest, or in fact other values important for competition law (consumer welfare). It is justified to say that Polish courts should apply the 'by effect' standard to RPM, especially as the fact is widely recognized that RPM generate, economically speaking, both positive and negative effects for consumers. Most importantly however, the burden of assessing their actual market effects should be placed on the Competition Authority rather than on market players.

\section{References}

Areeda, P. E. and Hovenkamp, H. (2004). Antitrust law. An Analysis of Antitrust Principles and Their Application. New York: Aspen Publishers.

Aziewicz, D. (2013). Pytanie o zasadność stosowania analizy ekonomicznej wobec minimalnych cen odsprzedaży w polskim prawie konkurencji, internetowy Kwartalnik Antymonopolowy i Regulacyjny, 3(2), 8-22.

Bolecki, A. (2013). Cechy szczególne franczyzy w prawie ochrony konkurencji. internetowy Kwartalnik Antymonopolowy i Regulacyjny, 7(2), 61-79.

Bork, R. (1978). The Antitrust Paradox, a policy at war with itself. New York: The Free Press. Coase, R. H. (1937). The Nature of the Firm. Economica, 4, 16.

Elhauge, E. (2007). Harvard, not Chicago: Which antitrust school drives recent supreme court decisions?. Competition Policy International, 3(2), 59-77.

Elzinga, K. G. and Mills, D. E. (2010). Leegin and procompetitive resale price maintenance. The Antitrust Bulletin, 55, 2, 349-379, http://dx.doi.org/10.1177/0003603x1005500204

Faul, J. and Nikpay, A. (2007). The EC Law of Competition. Oxford: Oxford University Press.

Grzejdziak, Ł. (2009). Zakaz ustalania cen odsprzedaży towarów. Warunek sine qua non efektywnej konkurencji czy nieproporcjonalne ograniczenie wolności gospodarczej, In: W. Szwajdler, H. Nowicki (ed.), Konstytucyjna zasada wolności gospodarczej. Toruń: TNOiK.

Hovenkamp, H. (2005). The Antitrust Enterprise, The principle and execution. Harvard: Harvard University Press, http://dx.doi.org/10.4159/9780674038820

Jones, A., Sufrin, B. (2009). EC Competition Law, Text, Cases, and Materials. Oxford: Oxford University Press.

Jurkowska Gomułka, A. (2012). Stosowanie zakazu porozumień ograniczających konkurencję zorientowane na ocenę skutków ekonomicznych? Uwagi na tle praktyki decyzyjnej Prezesa Urzędu Ochrony Konkurencji i Konsumentów w odniesieniu do ustawy o ochronie konkurencji i konsumentów z 2007 roku. internetowy Kwartalnik Antymonopolowy i Regulacyjny, 1(1), 33-49. 
Mathewson F. and Winter, R. (1998). The law and economics of resale price maintenance. Review of Industrial Organization, 13(1), 57-84.

Telser, L. (1960). Why Should Manufacturers Want Fair Trade. Journal of Law and Economics, 3, 86-105, http://dx.doi.org/10.1086/466564.

Turno, B. and Zawłocka -Turno, A. (2011). Ustalanie sztywnych lub minimalnych cen odsprzedaży jako porozumienie ograniczające konkurencję ze względu na cel (przedmiot) w prawie unijnym. Ruch Prawniczy, Ekonomiczny i Socjologiczny, 73(4), 71-87.

Skoczny, T. (ed.) (2014). Ustawa o ochronie konkurencji i konsumentów, Komentarz. Warszawa: C.H. Beck.

Stawicki, A. and Stawicki, E. (2010). Ustawa o ochronie konkurencji i konsumentów Komentarz. Warszawa: LexisNexis.

UOKiK (2014). Polityka konkurencji na lata 2014-2018. Warszawa: UOKiK.

UOKiK (2015), Polityka ochrony konkurencji i konsumentów, Warszawa: UOKiK. 